\title{
Role overload, knowledge acquisition and job satisfaction: an ambidexterity perspective on boundary-spanning activities of IT employees
}

Article

Accepted Version

Wang, G., Liu, X. and Liu, Y. (2019) Role overload, knowledge acquisition and job satisfaction: an ambidexterity perspective on boundary-spanning activities of IT employees. The International Journal of Human Resource Management, 30 (4). pp. 728-757. ISSN 1466-4399 doi:

https://doi.org/10.1080/09585192.2018.1494027 Available at https://centaur.reading.ac.uk/81628/

It is advisable to refer to the publisher's version if you intend to cite from the work. See Guidance on citing.

To link to this article DOI: http://dx.doi.org/10.1080/09585192.2018.1494027

Publisher: Routledge

All outputs in CentAUR are protected by Intellectual Property Rights law, including copyright law. Copyright and IPR is retained by the creators or other copyright holders. Terms and conditions for use of this material are defined in the End User Agreement. 


\section{www.reading.ac.uk/centaur}

\section{CentAUR}

Central Archive at the University of Reading

Reading's research outputs online 


\title{
Role overload, knowledge acquisition and job satisfaction: An ambidexterity perspective on boundary-spanning activities of IT employees
}

\begin{abstract}
Building upon the ambidexterity perspective, this study conceptualizes boundary-spanning activities as both transactional and learning to illuminate their different effects on IT employees' job satisfaction. Specifically, we offer an overarching theoretical framework rooted in ambidexterity by connecting the role theory and knowledge acquisition perspective to reconcile the inconsistency of extant findings. Role overload has a mediating effect on the relationship between boundary-spanning activities (both transactional and learning) and job satisfaction, whereas knowledge acquisition mediates the relationship between learning boundary-spanning activities and job satisfaction. Furthermore, high achievement motivation and learning goal orientation moderate the positive effect of learning boundary-spanning activities on job satisfaction. The quantitative analysis of IT employees in Chinese state-owned enterprises largely supports our hypotheses. We conclude this paper by discussing theoretical and managerial implications for ambidexterity, boundary spanning, and job satisfaction.
\end{abstract}

Keywords: ambidexterity, boundary spanning, role theory, knowledge acquisition, job satisfaction, IT employees 


\section{Introduction}

Despite the wide implementation of information technology (IT) systems, such as enterprise resource planning (ERP), in many global enterprises (Liang, Saraf, Xue \& Hu, 2007; Mithas, Tafti, Bardhan \& Goh, 2012), existing research shows that performance can differ greatly (Hassabelnaby, Hwang \& Vonderembse, 2012), which suggests that people are an important factor that affects the success or failure of ERP system. According to Somers and Nelson's (2004) survey on chief information officers (CIOs) of Fortune 500 companies, it shows that IT employees are the main factors that influence the successful implementation and application of IT systems. Building upon the importance of human side factors in organizations (Liu, Sarala, Xing \& Cooper, 2017), highly qualified IT employees are central to enterprises' successful implementation and application of IT systems.

However, effective management of IT employees appears to be a daunting challenge (Baroudi, 1985). There is a high turnover rate of highly qualified and skilled IT employees (Ang \& Slaughter, 2000; Bassellier \& Benbasat, 2004; Joseph, Boh, Ang \& Slaughter, 2012). The decrease in job satisfaction is believed to be the main reason for the high turnover rate of IT employees. Methods for improving IT employees' job satisfaction to reduce the turnover rate and help firms retain talent is an important issue for both HR practitioners and researchers (Ang \& Slaughter, 2000).

From the job design and analysis perspective (Sanchez \& Levine, 2012), IT job characteristics require IT employees undertake different roles in an organizational setting, such as IT infrastructure builder, business partner, project coordinator, system provider and technical leader (Guillemette \& Paré, 2012). This requires the IT employees to facilitate the information 
exchange between the IT department and other business departments as well as among different business units. Therefore, IT employees assume the role of boundary spanner (Pawlowski \& Robey, 2004; Levina \& Vaast, 2005). Traditionally, IT employees have been regarded as technical personnel (Enns, Thomas W. \& Prasad, 2006) or developers who only have extensive programming knowledge. However, enterprise IT systems have shifted from purely selfdeveloped to external commercial software suites, such as ERP systems, or general module and software packages for independent integration (Howcroft \& Light, 2010). Thus, IT employees should currently focus on how to solve business issues and how to lead business transformation and optimization through information systems (Ang \& Slaughter, 2000). Consequently, IT employees act as boundary spanners in coordinating with business units inside their enterprise, outside software suppliers, and external consulting firms in addition to other boundaryspanning activities.

Previous research has investigated the influence of boundary spanning activities of IT employees on their job satisfaction mainly from two different theoretical perspectives: role theory and information processing theory. According to role theory (Baroudi, 1985; Marrone, Tesluk \& Carson, 2007), IT employees who engage in boundary-spanning activity encounter role overload, and in such situations, they do not know how to proceed and feel high levels of stress, which leads to the decrease of job satisfaction. By contrast, according to the information processing theory (Carlile, 2004; Pawlowski \& Robey, 2004), IT employees who undertake boundary-spanning activities find the flow of information and the generation of new knowledge helpful, which improves their inner satisfaction and status in the organization. Therefore, it has a positive influence on job satisfaction. Thus, our research question is how the boundary- 
spanning activities of IT employees influence their job satisfaction.

To reconcile these contrasting views, the present study builds upon the organizational ambidexterity and HRM literature (O'Reilly \& Tushman, 2013; Junni, Sarala, Tarba, Liu \& Cooper, 2015; Junni, Sarala, Taras \& Tarba, 2013) to reconcile the inconsistent findings on IT employees' job satisfaction. Rooted in routine and non-routine tasks (e.g., Schwarzwald, Koslowsky, \& Ochana-Levin, 2004), we conceptualize that IT employees can engage in two distinctive types of boundary-spanning activities: transactional boundary-spanning activity with routine tasks (TB) and learning boundary-spanning activity with non-routine tasks (LB). Specifically, this article empirically examines IT employees in Chinese enterprises and discusses their boundary-spanning role and this role's relationship with job satisfaction.

This paper makes several contributions. First, by conceptualizing boundary-spanning activities into two dimensions - learning boundary-spanning activities (LB) and transactional boundary-spanning activities (TB) — our findings contribute to a more nuanced understanding of boundary-spanning activities through the ambidexterity lens. We found that an ambidexterity perspective can reconcile the seemingly diverging results on boundary-spanning activities on employee job satisfaction. Therefore, ambidexterity in HRM can address important questions related to job design for IT employees. Second, our research contributes to the ambidexterity literature by highlighting the importance of the occupational context of IT employees. The ambidexterity literature has not focused enough on the occupational contexts that can significantly influence individual and organizational behaviours. Our focal investigation on IT employees and their job satisfaction sheds some light on the importance of occupational contexts in the ambidexterity literature. 
This paper is organized as follows. First, we begin by reviewing the theoretical background of boundary spanning and ambidexterity, particularly the theoretical gap, and developing research hypotheses. Second, we describe the research design and quantitative research methodology. Next, we present our empirical results. We conclude by discussing theoretical and managerial implications as well as future research directions.

\section{Literature review and hypothesis development}

Boundary-spanning activities and inconsistency view on IT employees' job satisfaction

Boundaries exist widely between organizations and among an organization's different units. Between different organizations and in different professional departments in the same organization, there are specific norms, values, and mindsets and thus a boundary between them. A boundary is a cut-point and crossing point for an organization and environment that determines a discontinuity. Boundary-spanning activity refers to the communication and coordination that occur across the boundary of organization or organizational unit and promote the two sides of the boundary to conduct a series of material and information exchanges (Ancona \& Caldwell, 1992; Marrone et al., 2007). In boundary-spanning literature, it is emphasized that a boundary spanner plays an important role in connecting an organization and environment (Pawlowski \& Robey, 2004).

IT employees in enterprises can be regarded as boundary spanners who undertakes a set of boundary-spanning functions. From the perspective of boundary spanning, IT employees need to span the border between corporations and interact with members in another enterprise. In addition, they need to span the boundary of their department and interact with other 
department staff. In large enterprises, there is also differentiation within the specific function of a department, so IT employees may also need to span the border of different professionals in the same department. With the development of IT outsourcing and the change of IT employees' roles, some studies have noted the boundary-spanning role of IT employees. For example, Rutner, Hardgrave and McKnight (2008) found that IT employees need to extensively interact with those inside the IT department and staff in the other departments. In the process of interaction, IT employees can easily experience emotional dissonance, which impacts job satisfaction and turnover intention because they have to follow not only the norms of the IT profession itself but also that of other departments at the same time. Similarly, Pawlowski and Robey (2004) found that IT professionals promote boundary-spanning knowledge flows between IT and business departments within the organization. Their study concludes that there are four knowledge functions of boundary-spanning: spanning business departments, proposing hypotheses that challenge IT users, interpreting and explaining, and abandoning the ownership of knowledge. Ouyang, Ding and Guo (2012) also noticed in their case study that the IT department plays a boundary-spanning role in the Haier group's IT capability evolution process.

Boundary-spanning activities have been identified as an important component of IT jobs, particularly in systems analysis and design (Farwell \& Kuramoto, 1992). It is proposed in the case study that the role of information technology professionals is knowledge brokering in organizations. An IT professional may participate in internal knowledge transfer, particularly given their roles as knowledge brokers who facilitate the transfer of knowledge among organizational units, thereby contributing to their satisfaction and organizational learning (Pawlowski \& Robey, 2004). One study using a sample of IT employees from 28 different 
private sector companies found that boundary spanning activities had a positive influence on overall job satisfaction (Guimaraes \& Igbaria, 1992).

Boundary spanning can be either a positive or negative characteristic of a job. Some literature suggests the positive influence of boundary-spanning on job satisfaction. When assuming boundary-spanning activities, the knowledge acquisition of IT employees can increase their inner satisfaction and status in the organization; therefore, their job satisfaction can be enhanced (Pawlowski \& Robey, 2004). In particular, Pawlowski and Robey (2004) argue that IT employees are encouraged to undertake boundary-spanning activities, and they often cross interdepartmental boundaries to share information and leverage resources, which is regarded as among their most important roles in organizations. A system project provides IT employees the opportunity to interact with users and institutions so that they can directly access system information, such as program and user files.

While IT employees tend to welcome the challenges stemming from boundary spanning activities, boundary spanning can also be a source of stress (Lo, 2015). According to role theory (Kahn, Wolfe, Quinn, Snoek \& Rosenthal, 1964), as IT employees perform their boundary spanning roles, their behaviour is subject to the ambiguous and implicit expectations of outsiders and insiders, and job-related role ambiguity contributes significantly to employee stress. Afterwards, the experienced job stress leads to dissatisfaction and anxiety, which can decrease job satisfaction and job performance (Rigopoulou, Theodosiou, Katsikea \& Perdikis, 2012). Meanwhile, impression management is also an important issue that requires boundary spanners to conform to the (possibly conflicting) norms and expectations of various organizational units (Caldwell \& O'Reilly, 1982). As such, individuals in boundary spanning 
roles may experience role conflict and stress (Katz \& Kahn, 1978).

Many empirical studies demonstrate the detrimental effects of job-related role ambiguity or overload on job satisfaction and job performance. For example, an empirical test using data gathered from 316 bank branch managers indicates that role ambiguity negatively affects job satisfaction (Rigopoulou et al., 2012). Similar to IT employees, another study examined frontline service employees who play an important role in linking the organization to its customers and found that role conflict and role ambiguity have negative effects on job satisfaction (Bettencourt \& Brown, 2003). One study using 229 information systems personnel as a sample examines the antecedents of job satisfaction besides commitment and turnover intentions. Role ambiguity was found to be the most dysfunctional variable for information systems personnel, accounting for $22.2 \%$ of the variance in job satisfaction (Baroudi, 1985). In the review of turnover in information technology, professional role ambiguity and role conflict reduce job satisfaction, hence increasing one's intention to leave the organization. Similarly, factors such as workload should positively relate to turnover intention because of work exhaustion and reduced job satisfaction (Joseph, Ng, Koh \& Ang, 2007). Therefore, there is an important theoretical gap about the inconsistency view of boundary spanning activities on IT employees' job satisfaction.

An ambidexterity perspective on boundary-spanning activities

Organizational ambidexterity received considerable attention in organization and management studies and the HRM domain (O'Reilly \& Tushman, 2013; Junni, Sarala, Tarba, Liu \& Cooper, 2015). Beyond the notion of exploitation versus exploration, ambidexterity can 
be conceptualized when two opposing forces exist that conjointly affect organizational behaviours (Simsek, 2009)(Simsek, 2009)(Simsek, 2009). For instance, one study examined motivation-enhancing HR practices and found that the past performance-based incentive structure and future performance-based incentive structure can influence the productivity, motivation, and performance of employees (Ahammad, Mook Lee, Malul \& Shoham, 2015). Structural ambidexterity may foster the innovation of human resource management architecture (Huang, \& Kim, 2013). Another study conceptualized Confucianism and Legalism as philosophical foundations for employees' ambidextrous behaviours in considering both career progression and organizational commitment while managing supervisor-subordinate relationships (Xing, Liu, Tarba \& Wood, 2016). High-involvement HR systems may support exploratory and exploitative learning by encouraging firm employees to behave ambidextrously (Prieto-Pastor \& Martin-Perez, 2015). A systematic review on HRM in ambidexterity highlighted the importance of organizational factors to enhance our understanding of ambidexterity (Junni et al., 2015). For instance, one study revealed the importance of individual behaviour in organizational ambidexterity boundaries (Stokes, Moore, Moss, Mathews, Smith, $\&$ Liu, 2015). Therefore, we argue that an ambidexterity perspective on boundary-spanning activities can be conducive to advancing this literature stream and reconciling the inconsistency view on IT employees' job satisfaction, especially when the work context has a contingency role that affects managers' work experience, ambidexterity and performance (Mom, Fourne, \& Jansen, 2015).

On the one hand, although the boundary-spanning nature of IT work is noted in extant studies, few studies have been conducted directly on the specific content of IT employees' 
boundary-spanning activities and its influence on employees' job satisfaction. On the other hand, the extant literature on boundary spanning activities, such as their role and functions, cannot offer an appropriate answer to the contradictory findings on the relationship between IT employees' boundary spanning activities and job satisfaction. In discussing how to draw on and interlink diverse knowledge from MNC units to generate creative or innovative outcomes, the ability of collaborators to span the boundaries that separate their diverse knowledge is critical. They stated that "transferring knowledge in the sense of 'simple' processing of information, or even translating knowledge in the sense of developing a common meaning to overcome interpretive differences between contexts, is insufficient for solving non-routine problems" (Tippmann, Sharkey Scott, \& Parker, 2017). Here, the implication is that boundary spanners need to address non-routine problems to generate creative and innovative outcomes in addition to considering routine problems. The differing task content of boundary spanning activities affects what they feel and understand.

By building upon the ambidexterity perspective and literature on routine and non-routine work settings (Schwarzwald, Koslowsky, \& Ochana-Levin, 2004), we distinguish two types of boundary-spanning activities of IT staff: transactional boundary-spanning activities (TB) and learning boundary-spanning activities (LB). TB refers to IT employees' communication and coordination work with other departments' staff (including external units), which is more routine and requires less new knowledge. LB refers to the communication and coordination work with other departments' staff (including external units), which is less routine and less involved in new knowledge. The distinctive characteristics for the two dimensions of IT employees' boundary-spanning activities are the degree to which routine and the necessity for 
new knowledge in IT employees' communication and coordination with other departments' staff are displayed. From the perspective of role theory, when IT employees undertake transactional boundary-spanning activities, stress and low job satisfaction appear due to role overload (Marrone et al., 2007). However, from the perspective of the information processing theory, when IT employees assume boundary-spanning activities, knowledge acquisition can increase their inner satisfaction and status in the organization; therefore, their job satisfaction can be enhanced (Pawlowski \& Robey, 2004). Hence, we argue that an ambidexterity perspective to integrate both $\mathrm{TB}$ and $\mathrm{LB}$ can capture the complexity to offer a nuanced understanding of the implications of IT employees' boundary-spanning activities on their job satisfaction. We expect that the relationship between IT employees' TB and job satisfaction is consistent with the view of role theory, which has a negative impact on job satisfaction. The relationship between IT employees' LB and job satisfaction conforms to the information processing theory, which has a positive influence on job satisfaction. To reconcile both the positive and negative relationship on job satisfaction, an ambidexterity perspective may bring more clarity to IT employees' boundary-spanning activities. Furthermore, achievement motivation moderates the relationship between the effects of boundary-spanning activities and work outcomes. Therefore, a moderated mediation model is constructed as shown in Figure 1.

Figure 1 here

The model contains both mediating and moderating variables, which can answer not only how boundary-spanning activities affect work outcomes but also when the effect becomes 
stronger or weaker, thus revealing the social mechanisms more comprehensively (Edwards \& Lambert, 2007).

Information processing theory and knowledge acquisition

From the perspective of the information processing theory, knowledge acquisition and knowledge diffusion are the significant outcome variables of boundary-spanning activities (Pawlowski \& Robey, 2004; Wang et al., 2013). Previous research found that engaging in boundary-spanning activities helps promote knowledge sharing, information flows and the generation of new knowledge and consequently has a positive impact on the results of the work. Furthermore, research has shown that knowledge acquisition plays a mediating role between individual boundary-spanning activities and project performance in IT outsourcing situations (Wang et al., 2013).

From the interview with IT employees, it has been found that knowledge tends to merge together at the organizational level after the implementation of information system. However, knowledge tends to diversify at the individual level. IT employees are supposed to have more knowledge of IT systems and other business fields, especially when they are engaged in learning boundary-spanning activities (LB) with less routine and more new knowledge. When they engage in transactional boundary-spanning activities (TB) with more routine and less new knowledge, they do not feel noticeable knowledge acquisition. The knowledge research perspective not only emphasizes the understanding of the embedded business patterns in the system but also underlines the integration of the business knowledge in enterprises. At the micro level, IT employees from enterprises that manage information systems play an important role in the process of knowledge acquisition (Somers \& Nelson, 2004). Pawlowski and Robey (2004) 
argue that IT employees are encouraged to undertake boundary-spanning activities, and they often cross interdepartmental boundaries to share information and leverage resources, which is regarded as one of their most important roles in organizations. A system project provides IT employees the opportunity to work with users and institutions so that they can directly access system information, such as program and user files. In the pilot interview of our research, the IT staff deemed that attending the periodic user-staff meeting was the most popular and valuable learning experience. They said, "When we sit with our users, it offers the chance to transfer knowledge on a daily basis". This attests to the view that learning boundary-spanning activities (LB) for IT staff have a positive impact on knowledge acquisition. Additionally, Keller's (1978) empirical research, which finds a positive causal relationship between boundary-spanning activity and satisfaction, suggests that boundary spanners often have increased access to information compared to those with less boundary-spanning activity. This access to information may also provide the boundary spanner with greater feedback that concerns role activities and performance.

On the other hand, knowledge acquisition plays an important role in improving job satisfaction. Knowledge is the most precious resource in a company, and one can create new knowledge by restructuring and sharing the current knowledge. The individuals in other organizations are more likely to have important knowledge than the colleagues who work in the same place and thus brings new ideas and the source of innovation to the company. Some scholars find that IT employees have a greater need for achievement, autonomy and cognition. IT employees cross organizational boundaries to exchange information, which enhances the inflow of new ideas and innovation and thus increases the results of personal performance 
(Pawlowski \& Robey, 2004). Boundary-spanning activities with knowledge acquisition can also inspire interests and increase job autonomy to improve job satisfaction (Baroudi, 1985). IT employees are not only satisfied with needs in the personal business field but also strengthen their job satisfaction by transferring knowledge in the enterprise to take more responsibility for the strategy and business activities of their enterprise. Thus, we propose the following:

H1: Knowledge acquisition of IT staff plays a mediating role between learning boundaryspanning activities and job satisfaction. Learning boundary-spanning activities has a positive impact on knowledge acquisition (Hla), and knowledge acquisition has a positive impact on job satisfaction (H1b).

\section{Role theory and role overload}

Role theory suggests that team members have different types of expectations for mutual roles, which can influence their beliefs and ideas about appropriate role behaviours. Team members usually have direct cues on what rewards or punishments will result when displaying compliance or noncompliance with the role (Hackman, 1992).

Role overload as a type of mental strain takes place when the expectations of work exceed the available time, resources, or personal capability of the employee (Jensen, Patel, \& Messersmith, 2013). Role overload is associated with unachievable deadlines, working intensely, time pressure and conflicting commitments (Beehr, Walsh, \& Taber, 1976; Jensen et al., 2013). The existing literature suggests that the boundary-spanning activities of employees leads to role overload (Marrone et al., 2007).

Because boundary spanning is accompanied by significant stress and challenges, 
employees must work hard and expend a great deal of energy, which may lead to task overload. When individuals undertake boundary-spanning activities, they must actively manage a series of accidental events. These events either happen concurrently or successively so that it consumes significant energy and time. Boundary spanners must contact inside team members and outsiders to perform the external behaviours, spanning different subsystems; even some conflicting subsystems are therefore naturally necessary, which further leads to task overload and personal role conflict. Moreover, boundary spanning also must balance the process of focusing on internal activities (Choi, 2002). Team members find that when they adopt boundary-spanning activities, there are more requests for internal tasks, which will increase the number of role tasks and lead to task overload.

Because transactional boundary-spanning activities (TB) have a high degree of routine and involve less learning of new knowledge, IT employees feel bored and redundant and are easily aware of role overload. Similarly, although learning boundary-spanning activities (LB) has a low degree of routine and involves more learning of new knowledge, which can facilitate knowledge flow between IT departments and business departments, it is also necessary to acquire more knowledge of IT systems and other business fields, which will require additional time to study and digest, adding to the work and resulting in role overload.

The result of role overload is that employees do not know how to proceed and feel a high sense of pressure and stress. Employees experience role overload when available resources are perceived to be inadequate when considering perceived role demands, thus leading to distraction and stress (Kuvaas \& Buch, 2018). Some studies emphasized and examined the mediating effect of role overload. For example, it is found that HPWS utilization, when coupled 
with a low level of job control, tends to leave employees feeling greater levels of role overload and being more prone to turnover intentions (Jensen, Patel, \& Messersmith, 2013). When employees believe that their organization's HRM practices are intended to reduce organizational costs, they experience work overload, which translates to higher levels of emotional exhaustion (Shantz, Arevshatian, Alfes, \& Bailey, 2016).

Similarly, the research shows that role overload is a critical factor that negatively affects job-related attitudes and job satisfaction for employees occupying boundary-spanning positions (Rigopoulou et al., 2012). Team members who are under significant pressure, stress and work overload are more likely to feel frustrated and anxious. Moreover, they are less likely to help other team members, which results in a comprehensively unpleasant and unsatisfactory team experience. The experience may reduce the possibility that the team can keep the members for a long time. Thus, we propose the following:

H2: The role overload that IT employees perceive plays a mediating role between boundary-spanning activities and job satisfaction. Transactional boundary-spanning activities and learning boundary-spanning activities have positive impacts on role overload (H2a), while role overload has a negative impact on job satisfaction (H2b).

\section{Moderating the role of personality traits}

Although boundary spanners gain status and influence by obtaining unique knowledge, they experience serious role overload because they must cope with and manage stress. The foregoing has demonstrated that this type of role overload has a negative impact on job satisfaction. Whether the stress that boundary spanners perceived can be offset by the benefit 
from knowledge acquisition depends on their personality traits and particularly depends on whether boundary spanners are learning goal orientation and high achievement motivation.

It is proposed that the goals pursued by individuals create the framework for their interpretation and reactions to events or outcomes (Button, Mathieu, \& Zajac, 1996). Psychologists have identified two broad classes of underlying goals that individuals pursue in achievement settings. When a task is approached from a learning goal orientation, individuals strive to understand something new or to increase their level of competence in a given activity (Button, Mathieu, \& Zajac, 1996; VandeWalle \& Cummings, 1997). Achievement motivation or need for achievement refers to the degree to which individuals are motivated to achieve success and excellence in performing difficult and challenging tasks (McClelland, 1976). Individuals with high levels of achievement motivation seek excellence in performance, are competitive in work activities, and enjoy seeking out solutions to difficulties and challenges (Liu, Liu, \& Wu, 2010).

Extant studies indicate that when boundary spanners are faced with the heavy load, high pressure and role ambiguity that role overload brings, intrinsic motivations impact their job satisfaction (Rigopoulou et al., 2012). Boundary-spanning activity is heavy, challenging and stressful, and personal costs are considered less (Pawlowski \& Robey, 2004) when the team undertakes high-level boundary-spanning activities. The higher level of team boundaryspanning activities will connect the team with more valuable resources, such as information, progress feedback and support from the key external environment. The team acquires the knowledge through boundary-spanning, which can help them manage tasks strategically, meet project deadlines, and conduct job coordination that will reduce team members' pressure and 
role overload. These resources will help the team finish the task and meet expectations to decrease the stressors and needs of some individual team members and increase their job satisfaction (Pawlowski \& Robey, 2004). This view is consistent with the demand-resource model suggesting a balance between task demand and resources, which can influence employees' well-being and resilience (Huang, Luo, Liu \& Yang, 2016). Instead, in learning boundary-spanning activities, the improvement of creativity and working efficiency in addition to the increase of initiative and individual status that knowledge acquisition brings are not extremely attractive to employees who lack learning goal orientation and high achievement motivation. The benefits from knowledge acquisition cannot offset the pressure and dissatisfaction that role overload brings. Hence, we argue that when facing the same degree of learning boundary-spanning activities, IT employees who have high achievement motivation and learning goal orientation will attain more knowledge than those with low achievement and low learning goal orientation. In addition, they also display greater job satisfaction when having the same level of knowledge. Thus, we propose the following:

H3: High achievement motivation and learning goal orientation moderate the positive effect of learning boundary-spanning activities on job satisfaction.

\section{Research method}

\section{Measures development}

The measurement of boundary-spanning activities needs a special and situational behaviour scale that reflects specific behaviours to finish certain goals because there are no generally consistent boundary-spanning activities; similarly, the content of knowledge acquisition is also contextual. Therefore, our research first used the interview-based method to 
explore boundary-spanning activities for IT employees and relevant variables and developed new scales for boundary-spanning activities and knowledge acquisition.

From March 2013 to September 2013, we interviewed 6 leaders (department managers or vice managers) and 18 IT employees from six enterprises in China. China is an appropriate context to answer our research question because previous research shows that Chinese enterprises have been notably associated with relatively lower success rates of ERP implementation, with an estimated success rate of less than 20\% (Wang, Liu \& Wang, 2013). We conducted a qualitative data analysis on the boundary-spanning activities of IT employees and induced the dimensions of the constructs combining the existing literature. According to the results of the interview data, we established the definition of operational constructs and the scale items. We then invited an expert to confirm the content validity of the preliminary scale and modified the scale as needed. Afterwards, we randomized the items of the modified scale and asked six IT employees to categorize the items and test the content validity. According to the test results, we modified and deleted some items. Furthermore, we validated the discriminant validity and the convergent validity of the constructs in two rounds in terms of the classification process (Moore \& Benbasat, 1991; Carlson \& Herdman, 2012; Shaffer, DeGeest, \& $\mathrm{Li}, 2016)$. In particular, in the domain of information system research, "if an item was consistently placed within a particular category, then it was considered to demonstrate convergent validity with the related construct, and discriminant validity with the others. Secondly, in the sorting rounds, if the number of categories created by the various judges, the labels assigned to them, and the items included in them, were consistent, then scales based on these categories could also be said to convergent and discriminant validity." (Moore \& Benbasat, 
1991: 200).

We used the existing mature scales from the literature to measure other variables. We translated the English scales into Chinese, and a researcher with an overseas doctorate in this field tested the accuracy of the translation and phrase and revised them accordingly. We presented all the scales to a leading expert in the information management field to test the content validity. We then pre-tested those with a similar background to the research subjects and conducted a small-scale pilot study. According to the test results that we repeatedly revised, we combined the mature scales and newly developed scales to form a complete questionnaire and conducted the small-scale pre-test and pilot study. We distributed questionnaires to the Beijing Taiji Company, Jinhuili Technology Company, Computer Center of the Chongqing Municipal Foreign Economic and Trade Commission and the Electromechanical Imports and Exports Tendering Company and immediately received 30 valid questionnaires. We simplified the items and revised the wording according to the analysis result of the exploratory factor analysis to guarantee the credibility and the validity of the scale.

Transactional boundary-spanning activities and learning boundary-spanning activities have four items, respectively. For typical transactional boundary-spanning activities, the exemplar items are "install the IT tool for the business staff", "know or record the IT system complaints from the business staff"; for typical learning boundary-spanning activities, the exemplar item is "to learn the functions of new systems from other professionals (such as consultants), I often participate in the implementation of new application systems."

The items for knowledge acquisition are taken from Dhanaraj, Lyles, Steensma and Tihanyi (2004) and Tsang (2002), and the content of the specific knowledge is gained based on 
the analysis of interview data; we also referred to the extant literature on the necessary knowledge and skills for IT employees (Ang \& Slaughter, 2000; Bassellier \& Benbasat, 2004), which include business knowledge, business processes, cutting-edge IT technology, IT application knowledge, work attitudes and philosophy. The representative item is "I enrich my business knowledge through cooperating with colleagues in other departments." Items for role overload refer to Rutner et al. (2008) and Beehr et al. (1976), which has 6 items: "I feel that other people expect too much of me in my role."

The items for job satisfaction come from Bono and Judge (2003), which includes 5 items, such as "I feel happy on weekdays." The items for achievement motivation are adopted from Liu, Liu and Wu (2010), which include 4 items, such as "I am willing to deal with challenges from work." The items for learning goal orientation are adopted from Vandewalle and Cummings (1997), which include 5 items, such as "I am willing to choose challenging work to learn more."

The research controls the individual factors of IT employees, such as gender, age, position, salary equity, and job autonomy, which are found to have an impact on job satisfaction in the existing literature (e.g., Rutner et al., 2008). The items for salary equity are adopted from Shaw and Gupta (2001), which is measured from the comparison between components internal and external to the organization. It includes 4 items, such as "My salary level is reasonable compared with people who have the same skills outside the company." The items for job autonomy from Rutner et al. (2008) include 4 items, such as "In my work, I usually do not need to consult with my direct leader and then make the final decision."

To monitor the quality of the questionnaire, we added two reverse items that do not belong 
to the scales of two boundary-spanning activities.

\section{Sample and data collection}

To control the influence from the difference in industrial and organizational levels on the research results, this research conducted data collection among all employees in one stateowned enterprise in Chongqing, China. The researchers directly contacted the company's president and explained the research purpose to ask for his support. With the support of the president, the company issued a formal notification recommending the questionnaire survey to those who will complete the questionnaire and encouraged them to support this study. The researchers then distributed and collected the questionnaires with the help of the HR manager. The detailed process had two steps: first, IT employees carried out the questionnaire anonymously. For employees who were working in the company at the time, the researchers gave the questionnaire on site; for those who were expatriated or on a business trip, the researchers sent the questionnaire by email. To ensure the quality of question answering, the employees were told explicitly that it was an anonymous survey and request that they complete it truthfully. Second, regarding personal information such as department, age, gender, educational background, positions and titles, the researchers confirmed their name (for the questionnaire by email, the researchers confirmed this directly using the email address) with the support of HR manager. The direct leaders evaluated the level of their subordinates' job satisfaction. Finally, the leaders evaluated 113 employees, and the employees completed 112 questionnaires.

After matching the information, the researchers formed the data from 112 samples. As 
mentioned above, we calculated the difference between the score of the reverse item "I usually do not go to industrial experience exchange meetings to which my company dispatches employees" plus the average score of learning boundary-spanning activities scale and the difference between the score of the reverse item "I have no interest in the opportunities for me to develop new skills and new knowledge" and the average score of the learning goal orientation scale. If the two differences are equal to zero statistically, this shows that the participant is not serious and that this questionnaire should not be used. After the above process, 110 valid questionnaires remained.

Among the employees who took part in the survey, male respondents accounted for $69.8 \%$, most of whom hold master's degrees $(60.7 \%)$, and their working tenures in the present company were mostly from 3 to 10 years (44.9\%), which fully fits the typical characteristics of IT employees in state-owned enterprises. Most participants are average employees (81.1\%), which also meets the requirement of our research objects.

\section{Data analysis and results}

Reliability, validity and test of the common method error

We conducted a confirmatory factor analysis on 42 items from the nine constructs, which are respectively job satisfaction, role overload, knowledge acquisition, learning boundaryspanning activities, transactional boundary-spanning activities, achievement motivation, learning goal orientation, job autonomy, and equity of reward. The results show that the 9-factor model has the best fitting effect $\left(\mathrm{df}=783, \mathrm{X}^{2}=1016.98, \mathrm{RMSEA}=0.052, \mathrm{NNFI}=0.95, \mathrm{CFI}\right.$ $=0.95$, IFI $=0.95)$. Additionally, the loadings of the four items of role overload, learning 
boundary-spanning activities and transactional boundary-spanning activities are between 0.5 and 0.6, and the rest of the items' loadings are above 0.6. Harman's single factor test shows that the single factor analysis model does not match the sample data well. To test the common method error of job satisfaction, we calculated the weighted value of job satisfaction from supervisors' evaluation and employees' self-evaluation (the weight for both is 50\%). Additionally, the results of the analysis have no substantial differences from those of the hypothesis test in terms of employee self-evaluation. Therefore, there is no significant common method error in the research. Table 1 shows the descriptive statistics and correlation coefficient of the variables.

\section{Table 1 here}

\section{Hypothesis testing}

First, a hierarchical regression is conducted to test the mediating effect. From the results of the hierarchical regression in Table 2, learning boundary-spanning activities has a significant influence on knowledge acquisition, and knowledge acquisition enhances job satisfaction significantly, which shows that $\mathrm{H} 1 \mathrm{a}$ and $\mathrm{H} 1 \mathrm{~b}$ are supported initially. Additionally, the finding demonstrates that knowledge acquisition plays a mediating role between learning boundaryspanning activities and job satisfaction. The results also show that transactional boundaryspanning activities significantly influence role overload but that learning boundary-spanning activities does not prominently improve the level of role overload. At the same time, role overload distinctly decreases the level of job satisfaction. Therefore, the results support $\mathrm{H} 2 \mathrm{a}$ but not H2b. Finally, model 2 with job satisfaction as a dependent variable reveals that transactional boundary-spanning activities has no significant impact on job satisfaction, so the 
mediating effect of role overload between boundary-spanning activities and work results is not supported, and $\mathrm{H} 2$ is partially supported.

Therefore, for the impact on job satisfaction, the information processing theory is supported, and role theory is partially supported.

Table 2 here

Having followed the above steps, we found that knowledge acquisition plays a mediating effect between learning boundary-spanning activities and job satisfaction. However, this study's model contains both moderating effects from learning goal orientation and achievement motivation. For such a moderated mediation model, Edwards \& Lambert (2007) argued that the results can be analysed by the total effect moderation model to overcome the disadvantage of separating the mediating effect from the moderating effect. Following the steps they recommended, this study constructed the following two equations:

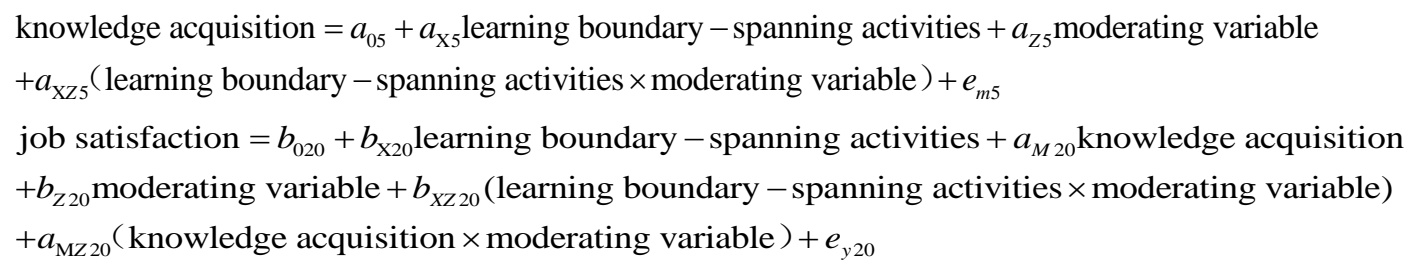

Equation (1) is used to test the influence in the first stage (i.e., learning boundary-spanning activities on knowledge acquisition), and equation (2) is used to examine the influence in the second stage (i.e., knowledge acquisition on job satisfaction) and the direct effect (i.e., learning boundary-spanning activities on job satisfaction). For the two moderating variables, achievement motivation and learning goal orientation, the study calculates the least square estimation of regression parameters (here, the default loss function is adopted, and the 
regression coefficient from the multiple linear regression is the initial value) by the contained nonlinear regression shown in Table 3. All variables have been centralized before computing. One thousand sets of estimates are obtained by repeating the bootstrap method 1000 times, after which they are imported into an Excel file for calculation, and the coefficients of the first stage (from antecedent variables to mediating variables), the second stage (from mediating variables to outcome variables), direct effect, indirect effect and total effect are obtained with the moderating variable in both the high group and low group, and the difference values of each effect coefficients are also gained. Additionally, the 1000 group estimate is employed to calculate the bias-corrected confidence intervals, based on which the statistical significance of each stages' effects and their differences are determined (cf. Table 4).

Table 3 and Table 4 here

Table 4 shows that similar results are found with the two types of mediating variables, achievement motivation and learning goals orientation. Under different levels of achievement motivation and learning goal orientation, there are significant differences in the effect of the first stage. In other words, IT employees who have a higher level of achievement motivation and learning goal orientation will make better use of learning boundary-spanning activities to obtain more knowledge. In addition, the results also show that the second stage has significant effects; in other words, knowledge acquisition has a noteworthy effect on job satisfaction. Although this may be because of sample size, the differences of the effects between high and low groups are not significant statistically; however, for IT employees who have low level of achievement motivation and learning goal orientation, it has a significant influence at the 5\% significance level; for the high level, it only has a significant effect at the $10 \%$ significance 
level. The results suggest that for IT employees with lower levels of achievement motivation and learning goal orientation, they are more likely to be satisfied with knowledge acquisition, and only a small amount of knowledge acquisition can lead to greater job satisfaction. This inference needs to be tested by using larger samples. The above results show that $\mathrm{H} 3$ is partly supported. Finally, the results also suggest that the direct effect of knowledge acquisition to job satisfaction is not significant, while the indirect effect is significant, which means knowledge acquisition plays a fully mediating variable for learning boundary-spanning activities. Figures $2 \mathrm{a}$ to $2 \mathrm{~d}$ are diagrams of the mediating effects under different levels of moderating variables.

Figure $2 \mathrm{a}, 2 \mathrm{~b}, 2 \mathrm{c}$ and $2 \mathrm{~d}$ here

To show the moderating effect more explicitly, Figure $3 a$ and Figure $3 b$ draw out the figures of the two moderating variables in the first phase. Additionally, for better understanding, the coordinates are decentralized, which does not affect the interpretation.

Figure $3 a$ and $3 b$ here

\section{Discussion and Conclusion}

\section{Theoretical contribution}

First, this present research resolves the contradictory explanations about the effect of boundary-spanning activities on job satisfaction, as predicted in the role theory and information processing theory by using the ambidexterity perspective. By conceptualizing boundaryspanning activities into two dimensions, learning boundary-spanning activities (LB) and transactional boundary-spanning activities (TB), our findings contribute to a nuanced understanding of boundary spanning activities through the ambidexterity lens. In so doing, we advance the existing research on boundary-spanning that has not yet proposed this distinction 
and usually regards boundary-spanning activities as a single dimension construct. We found that an ambidexterity perspective can reconcile the seemingly diverging results on boundaryspanning activities on employees' job satisfaction. Therefore, ambidexterity in HRM can address important questions relative to the job design (Sanchez \& Levine, 2012) of IT employees.

Second, our research contributes to the ambidexterity literature by highlighting the importance of occupational context. The ambidexterity literature has yet not paid enough attention to the occupational contexts that can significantly influence individual and organizational behaviours (Mom, et al, 2015). Our focal investigation on IT employees and their job satisfaction shed some light on the occupational contexts in the ambidexterity literature. IT employees are often taken as intermediaries in promoting the information exchange between IT departments and other business departments or between business departments; therefore, they undertake a boundary-spanning role (Pawlowski \& Robey, 2004; Levina \& Vaast, 2005). However, the existing literature lacks in-depth exploration on IT staff boundary-spanning activities. To fill this gap, our research focuses on IT employees' work practices in Chinese enterprises, investigates the boundary-spanning activities of IT employees, and explores its relationship between boundary-spanning activities with job satisfaction. Our empirical setting of IT employees in Chinese enterprises may also engender a contextualized understanding of ambidexterity and HRM. Our research found that the peculiar occupational characteristics can have an important bearing on employee task allocation, role expectation, and job satisfaction. 
Our research can show the managerial implications for HRM. This study reconciles the confusion from two theoretical perspectives of IT supervisors, i.e., whether boundary-spanning activities increase an IT employee's job satisfaction. The study explains the circumstances under which boundary-spanning activities can promote job satisfaction and in what type of situation boundary-spanning activities have a negative impact on job satisfaction. The conclusion has important implications for business managers and gives them directions in IT employees' work design. Our study also joins the conversation on job analysis (Sanchez \& Levine, 2012) highlighting the importance of context in designing jobs in terms of the nature of the task involving more routine or less routine work. The nature of the job tasks may result in diverging consequences on job satisfaction. The competence modelling (Sanchez \& Levine, 2009) may be helpful in designing and offering the types of tasks to employees to fulfil their job satisfaction, respectively. Furthermore, HR managers should pay special attention to the improvement of IT employees' satisfaction and their loyalty to the enterprise to control the turnover rate. This study indicates that HR managers may find ways to minimize role overload from transactional boundary-spanning activities and increase learning boundary-spanning activities where possible. An ambidexterity perspective can be beneficial for IT supervisor to understand the behavioural outcome of their IT employees.

\section{Limitations and future research direction}

We suggest future research can build upon our conceptualization on boundary-spanning activities from the ambidexterity perspective. Although we highlight the occupational context of IT employees, we suggest future research can expand the sample of this study to other 
industries and occupations. Boundary-spanning activities also prevail in other sectors and fields, such as international business and management. Therefore, a comparative perspective may help to refine our theoretical framework and validate our findings from large samples. As boundaryspanning activities may lead to role conflict and role ambiguity, future research can further analyse the mediating effect of these variables between boundary-spanning activities and work outcome. Additionally, the ambiguity can be perceived and interpreted differently by different employees and leaders (Xing \& Liu, 2015), and therefore, we suggest that future work take a qualitative approach to exploring the relationship between ambiguity and boundary-spanning activities.

\section{Conclusions}

This research explains the various effects that IT employees' different boundary-spanning activities from an ambidexterity perspective have on job satisfaction by distinguishing boundary-spanning activities into two dimensions: TB and LB. Research shows that when IT employees undertake TB, role overload leads to a decrease in job satisfaction; when IT employees undertake LB, which contributes to the promotion of knowledge acquisition, this improves inner satisfaction and upgrades employees' status in organizations and therefore has a positive effect on job satisfaction. Knowledge acquisition plays a fully mediating role in the positive impact of LB on job satisfaction, LB has a positive impact on job satisfaction mainly through knowledge acquisition. From the ambidexterity perspective of boundary spanning, this study resolves the contradictions in the previous literature by separating boundary-spanning activities into two dimensions and reveals 'how' boundary-spanning activities affect work 
outcomes. At the same time, the results from the moderated mediation model show that IT employees' achievement motivation and learning goal orientation have a moderating function in LB's influence on knowledge acquisition. Since the ratio of IT employees' TB to LB is to some extent the result of job design and task arrangement, this conclusion therefore shows that IT employees with a higher level of achievement motivation and learning goal orientation can make better use of the opportunity of learning boundary-spanning behaviour to achieve more knowledge, and this study reveals 'when' boundary-spanning activities make work outcomes stronger.

\section{Appendix: list of scales}

\section{Transactional boundary spanning activities (items)}

I often install IT tools for business staff.

I often resolve common problems in IT systems encountered by the business staff in their daily operation.

I often know about or record IT system complaints from the business staff.

I always maintain IT system platforms at the request of the business staff.

Learning boundary-spanning activities ( 4 items)

I often investigate the status quo of business segments.

I often analyse and explore the system requirements for business segments.

I often communicate with the business staff to attain their feedback on me or my department.

To learn the functions of new systems from other professionals (such as consultants), I often participate in the implementation of new application systems.

\section{Role overload (6 items)}

I feel that other people expect too much of me in my role.

It often seems like I have too much work for one person to do.

I feel that the number of requests, problems, or complaints I deal with is more than expected.

I feel that the amount of work I do interferes with how well it is done

I feel busy or rushed.

I feel pressured.

\section{Knowledge acquisition (6 items)}

The extent to which you have learned through cooperating with colleagues in other departments:

I enrich my business knowledge.

I become acquainted with the business process in our company. 
I extend the scope of IT application knowledge.

I become acquainted with the cutting-edge technology of IT applications.

I learn about the various types of information needed in my position.

I absorb others' work attitudes and philosophy.

\section{Achievement motivation (4 items)}

I am willing to deal with challenges from work.

To fulfil tasks, I would like to take risks.

I am willing to set and achieve realistic goals.

I would like to seek satisfaction from accomplishing a difficult task.

\section{Learning goal orientation (5 items)}

I often read materials related to my work to improve my abilities.

I am willing to choose challenging work to learn more.

I enjoy challenging and difficult tasks at work where I can learn new skills.

For me, development of my work ability is important enough to take risks.

I prefer to work in situations that require a high level of ability and talent.

\section{Job autonomy (4 items)}

In my work, I usually do not need to ask my direct leader and then make a final decision.

Usually, my direct supervisor does not have to approve my decisions before I can take action.

Rather than asking my director, I usually make my own decisions about what to do on the job.

I can usually do what I want in this job without consulting my direct supervisor.

\section{Salary equity (4 items)}

Compared to those in my company who do a job similar to mine, my pay level is fair.

My salary level is reasonable compared to those who have the same skills outside the company.

Compared with my input, my level of pay is fair.

Overall, the compensation I receive here is fair.

\section{Job satisfaction (5 items)}

Most days, I am enthusiastic about my work.

I feel fairly satisfied with my present job.

I find real enjoyment in my work.

I feel very happy on weekdays.

I consider my job rather pleasant.

\section{References:}

Adams, J. S. (1980). Interorganizational processes and organization boundary activities. In B. Staw \& L. Cummings. Research in Organizational Behavior (pp. 321-355). Greenwich, CT: Cummings, JAI Press.

Ahammad, M. F., Mook Lee, S., Malul, M. \& Shoham, A. (2015). Behavioral ambidexterity: The impact of incentive schemes on productivity, motivation, and performance of employees in commercial banks. Human Resource Management, 54, s45-s62. doi:10.1002/hrm.21668

Aldrich, H. \& Herker, D. (1977). Boundary spanning roles and organization structure. The Academy of Management Review, 2, 217-230. doi:10.5465/AMR.1977.4409044

Ancona, D. G. \& Caldwell, D. F. (1988). Beyond task and maintenance: Defining external functions in groups. Group \& Organization Studies, 13, 468-494. doi:10.1177/105960118801300405

Ancona, D. G. \& Caldwell, D. F. (1992). Bridging the boundary: External activity and performance in 
organizational teams. Administrative Science Quarterly, 37, 634-665. doi:10.2307/2393475

Ang, S. \& Slaughter, S. (2000). The missing context of information technology personnel: A review and future directions for research. In R. W. Zmud. Framing the domains of IT management: Projecting the future through the past (pp. 305-327). Cincinnati, OH: Pinnaflex Educational Resources, Inc.

Baroudi, J. J. (1985). The impact of role variables on is personnel work attitudes and intentions. MIS Quarterly, 9, 341-356. doi:10.2307/249234

Bassellier, G. X. \& Benbasat, I. (2004). Business competence of information technology professionals: Conceptual development and influence on IT-Business partnerships. MIS Quarterly, 28, 673-694. doi:10.1017/CBO9781107415324.004

Bechky, B. A. (2003). Sharing meaning across occupational communities: The transformation of understanding on a production floor. Organization Science, 14, 312-330. doi:10.1287/orsc.14.3.312.15162

Beehr, T. A., Walsh, J. T., \& Taber, T. D. (1976). Relationship of stress to individually and organizationally valued states: higher order needs as a moderator. Journal of Applied Psychology, 61, 41-7. doi:10.1037/00219010.61.1.41

Bettencourt, L. A. \& Brown, S. W. (2003). Role stressors and customer-oriented boundary-spanning behaviors in service organizations. Journal of the Academy of Marketing Science, 31, 394-408. doi:10.1177/0092070303255636

Bono, J. E. \& Judge, T. A. (2003). Self-concordance at work: Toward understanding the motivational effects of transformational leaders. Academy of Management Journal, 46, 554-571. doi:10.2307/30040649

Button, S. B., Mathieu, J. E., \& Zajac, D. M. (1996). Goal orientation in organizational research: A conceptual and empirical foundation. Organizational Behavior and Human Decision Processes, 67, 26-48. doi:10.1006/obhd.1996.0063

Caldwell, D. F. \& O'Reilly, C. A. (1982). Boundary spanning and individual performance: The impact of selfmonitoring. Journal of Applied Psychology, 67, 124-127. doi:10.1037/0021-9010.67.1.124

Carlile, P. R. (2004). Transferring, translating, and transforming: An integrative framework for managing knowledge across boundaries. Organization Science, 15, 555-568. doi:10.1287/orsc.1040.0094

Carlson, K.D. \& Herdman, A.O. (2012). Understanding the Impact of Convergent Validity on Research Results, Organizational Research Method, 15(1), 17-32.

Choi, J. N. (2002). External activities and team effectiveness: Review and theoretical development. Small Group Research, 33, 181-208. doi:10.1177/104649640203300202

Dhanaraj, C., Lyles, M. A., Steensma, H. K. \& Tihanyi, L. (2004). Managing tacit and explicit knowledge transfer in IJVs: The role of relational embeddedness and the impact on performance. Journal of International Business Studies, 35, 428-442. doi:10.1057/palgrave.jibs.8400098

Edwards, J. R. \& Lambert, L. S. (2007). Methods for integrating moderation and mediation: A general analytical framework $\quad$ using moderated path analysis. Psychol Methods, 12, 1-22. doi:10.1037/1082-989X.12.1.1

Enns, H. G., Thomas W., F. \& Prasad, J. (2006). Beyond stereotypes of IT professionals: Implications for IT HR practices. Communications of the ACM, 49, 105-109. doi:10.1145/1121949.1121956

Farwell, D. W. \& Kuramoto, L. (1992). A new paradigm for is. Information Systems Management, 9, 7-14. doi:10.1080/10580539208906859

Guillemette, M. G. \& Paré, G. (2012). Toward a new theory of the contribution of the IT function in organizations. MIS Quarterly, 36, 529-551. doi:10.1080/1354570042000267617

Guimaraes, T. \& Igbaria, M. (1992). Determinants of turnover intentions: Comparing IC and is personnel. Information Systems Research, 3, 273-303. doi:10.1287/isre.3.3.273

Hackman, J. R. (1992). Group influences on individuals in organizations. In M. D. Dunnette \& L. H. Hough. 
Handbook of industrial and organizational psychology (pp. 199-267). Palo Alto, CA: Consulting Psychologists Press.

Hassabelnaby, H. R., Hwang, W. \& Vonderembse, M. A. (2012). The impact of ERP implementation on organizational capabilities and firm performance. Benchmarking: An International Journal, 19, 618-633. doi:10.1108/14635771211258043

Howcroft, D. \& Light, B. (2010). The social shaping of packaged software selection. Journal of the Association for Information Systems, 11, 122-148.

Huang, J. and Kim, H.J. 2013. Conceptualizing structural ambidexterity into the innovation of human resource management architecture: The case of LG Electronics, International Journal of Human Resource Management, 24 (5), pp. 922-943

Huang, Y., Luo, Y., Liu, Y. \& Yang, Q. (2016). An Investigation of interpersonal ties in interorganizational exchanges in emerging markets: A boundary-spanning perspective. Journal of Management, 42, 1557-1587. doi:10.1177/0149206313511115

Jensen, J. M., Patel, P. C., \& Messersmith, J. G. (2013). High-performance work systems and job control: consequences for anxiety, role overload, and turnover intentions. Journal of Management, 39, 1699-1724. doi: 10.1177/0149206311419663

Joseph, D., Boh, W. F., Ang, S. \& Slaughter, S. A. (2012). The career paths less (or more) traveled: A sequence analysis of IT career histories, mobility patterns, and career success. MIS Quarterly, 36, 427-452.

Joseph, D., Ng, K., Koh, C. \& Ang, S. (2007). Turnover of information technology professionals: A narrative review, meta-analytic structural equation modeling, and model development. MIS Quarterly, 31, 547-577. doi:10.1055/s-0029-1225353

Junni, P., Sarala, R., Taras, V., and Tarba, S.Y. (2013). Organizational Ambidexterity and Performance: A MetaAnalysis. Academy of Management Perspectives, 27 (4), pp. 299-312.

Junni, P., Sarala, R. M., Tarba, S. Y., Liu, Y. \& Cooper, C. L. (2015). Guest editors' introduction: The role of human resources and organizational factors in ambidexterity. Human Resource Management, 54, s1-s28. doi:10.1002/hrm.21772

Kahn, R. L., Wolfe, D. M., Quinn, P. R., Snoek, J. D. \& Rosenthal, R. A. (1964). Organizational stress: Studies in role conflict and ambiguity. New York: John Wiley \& Sons.

Katz, D. \& Kahn, R. L. (1978). The Social Psychology of Organizations (2nd edition). New Jersey: John Wiley \& Sons, Inc.

Keller, R. T. (1978). Boundary-spanning activity, role dynamics, and job satisfaction: A longitudinal study. Journal of Business Research, 6, 147-158. doi:10.1016/0148-2963(78)90005-X

Kuvaas, B. \& Buch, R. (2018). Leader-member exchange relationships and follower outcomes: The mediating role of perceiving goals as invariable. Human Resource Management, 57, 235-248. doi:10.1002/hrm.21826

Levina, N. \& Vaast, E. (2005). The emergence of boundary spanning competence in practice: Implications for implementation and use of information systems. MIS Quarterly, 29, 335-363. doi:10.2307/25148682

Liang, H., Saraf, N., Hu, Q. \& Xue, Y. (2007). Assimilation of enterprise systems: The effect of institutional pressures and the mediating role of top management. MIS Quarterly, 31, 59-87.

Liu, Y., Liu, J. \& Wu, L. (2010). Are you willing and able? Roles of motivation, power, and politics in career growth. Journal of Management, 36, 1432-1460. doi:10.1177/0149206309359810

Liu, Y., Sarala, R.M., Cooper, C. \& Xing, Y. (2017). Human side of collaborative partnerships: A microfoundational perspective. Group \& Organization Management, 42(2):151-162.

Lo, J. (2015). The information technology workforce: A review and assessment of voluntary turnover research. Information Systems Frontiers, 17, 387-411. doi:10.1007/s10796-013-9408-y 
Marrone, J. A., Tesluk, P. E. \& Carson, J. B. (2007). A multilevel investigation of antecedents and consequences of team member boundary-spanning behavior. Academy of Management Journal, 50, 1423-1439. doi: $10.2307 / 20159482$

Miles, R. (1980). Organizational boundary roles. In C. C. Cooper \& R. Payne. Current concerns in occupational stress (pp. 61-96). Chinchester, England: John-Wiley.

Mithas, S., Tafti, A., Bardhan, I. \& Goh, J. M. (2012). Information technology and firm profitability: Mechanisms and empirical evidence. MIS Quarterly, 36, 205-224.

Mom, T. J. M., Fourne, S. P. L., and Jansen, J. J. P. (2015). Managers' work experience, ambidexterity and performance: The contingency role of the work context. Human Resource Management, 24, s133-s153.

Moore, G. C. \& Benbasat, I. (1991). Development of an instrument to measure the perceptions of adopting an information technology innovation. Information Systems Research, 2, 192-222. doi:10.1287/isre.2.3.192

Mors, M. L. (2010). Innovation in a global consulting firm: When the problem is too much diversity. Strategic Management Journal, 31, 841-872. doi:10.1002/smj.837

Nwankpa, J. K., Roumani, Y., Brandyberry, A., Guiffrida, A. \& Hu, M. (2013). Understanding the link between initial ERP systems and ERP-enabled adoption. Information Resources Management Journal, 26, 18-39. doi:10.4018/irmj.2013100102

O'Reilly, C. A. \& Tushman, M. L. (2013). Organizational ambidexterity: Past, present, and future. The Academy of Management Perspectives, 27, 324-338. doi:10.5465/amp.2013.0025

Ouyang, T. H., Ding, L. \& Guo, R. J. (2012). Co-evolution of boundary spanning and IT capability: Case study on Haier's information system. China Industrial Economics (in Chinese) 128-140.

Pawlowski, S. D. \& Robey, D. (2004). Bridging user organizations: Knowledge brokering and the work of information technology professionals. MIS Quarterly, 28, 645-672. doi:10.2307/25148658

Prieto-Pastor, I. and Martin-Perez, V. (2015). Does HRM generate ambidextrous employees for ambidextrous learning? The moderating role of management support. International Journal of Human Resource Management, 26(5), 589-615.

Rigopoulou, I., Theodosiou, M., Katsikea, E. \& Perdikis, N. (2012). Information control, role perceptions, and work outcomes of boundary-spanning frontline managers. Journal of Business Research, 65, 626-633. doi:10.1016/j.jbusres.2011.03.001

Rutner, P. S., Hardgrave, B. C. \& McKnight, D. H. (2008). Emotional dissonance and the information technology professional. MIS Quarterly, 32, 635-652.

Sanchez, J.I. \& Levine, E.L (2009). What is (or should be) the difference between competency modeling and traditional job analysis? Human Resource Management Review, 19, 53-63.

Sanchez, J.I. \& Levine, E.L (2012). The Rise and Fall of Job Analysis and the Future of Work Analysis, Annual Review of Psychology, 63:397-425.

Schwarzwald, J., Koslowsky, M., \& Ochana-Levin, T. (2004). Usage of and compliance with power tactics in routine versus nonroutine work settings. Journal of Business and Psychology, 3, 385-402. doi:10.1023/B:JOBU.0000016713.86935.1b

Shaffer, J.A., DeGeest, D. \& Li, A. (2016). Tackling the Problem of Construct Proliferation: A Guide to Assessing the Discriminant Validity of Conceptually Related Constructs, Organizational Research Methods, 19(1), 80110.

Shantz, A., Arevshatian, L., Alfes, K., \& Bailey, C. (2016). The effect of HRM attributions on emotional exhaustion and the mediating roles of job involvement and work overload. Human Resource Management Journal, 26, 172-191. doi:10.1111/1748-8583.12096

Shaw, J. D. \& Gupta, N. (2001). Pay fairness and employee outcomes: Exacerbation and attenuation effects of 
financial need. Journal of Occupational and Organizational Psychology, 74, 299-320. doi:10.1348/096317901167370

Simsek, Z. (2009). Organizational ambidexterity: Towards a multilevel understanding. Journal of Management Studies, 46, 597-624. doi:10.1111/j.1467-6486.2009.00828.x

Somers, T. M. \& Nelson, K. G. (2004). A taxonomy of players and activities across the ERP project life cycle. Information \& Management, 41, 257-278. doi:10.1016/S0378-7206(03)00023-5

Stokes, P., Moore, N., Moss, D., Mathews, M., Smith, S. M., and Liu, Y. (2015). The microdynamics of intraorganizational and individual behavior and their role in organizational ambidexterity boundaries. Human Resource Management, 54, s63-s86

Tippmann, E., Sharkey Scott, P., \& Parker, A. (2017). Boundary capabilities in MNCs: Knowledge transformation for creative solution development. Journal of Management Studies, 54, 455-482. doi:10.1111/joms.12253

Tortoriello, M. \& Krackhardt, D. (2010). Activating cross-boundary knowledge: The role of simmelian ties in the generation of innovations. Academy of Management Journal, 53, 167-181. doi:10.5465/AMJ.2010.48037420

Tsang, E. W. K. (2002). Acquiring knowledge by foreign partners from international joint ventures in a transition economy: Learning-by-doing and learning myopia. Strategic Management Journal, 23, 835-854. doi:10.1002/smj.251

Tushman, M. L. (1977). Special boundary roles in the innovation process. Administrative Science Quarterly, 22, 587-605. doi:10.2307/2392402

Tushman, M. L. \& Scanlan, T. J. (1981). Boundary spanning individuals: Their role in information transfer and their antecedents. Academy of Management Journal, 24, 289-305. doi:10.2307/255842

Tushman, M. L. \& Scanlan, T. J. (1981). Characteristics and external orientations of boundary spanning individuals. Academy of Management Journal, 24, 83-98. doi:10.2307/255825

Vandewalle, D. \& Cummings, L. L. (1997). A test of the influence of goal orientation on the feedback-seeking process. Journal of Applied Psychology. doi:10.1037/0021-9010.82.3.390

Wang, Y. J., Liu, Y. \& Wang, L. (2013). The study on the impact caused by individual boundary-spanning activities on project performance of outsourcing at initial stage: The verification of intermediary role in interfirm knowledge utilization. East China Economic Management (in Chinese).

Xing, Y. \& Liu, Y. (2015). Poetry and leadership in light of ambiguity and logic of appropriateness. Management and Organization Review, 11, 763-793. doi:10.1017/mor.2015.18

Xing, Y., Liu, Y., Tarba, S. \& Wood, G. (2016). A cultural inquiry into ambidexterity in supervisor-subordinate relationship. The International Journal of Human Resource Management 1-29. doi:10.1080/09585192.2015.1137619 


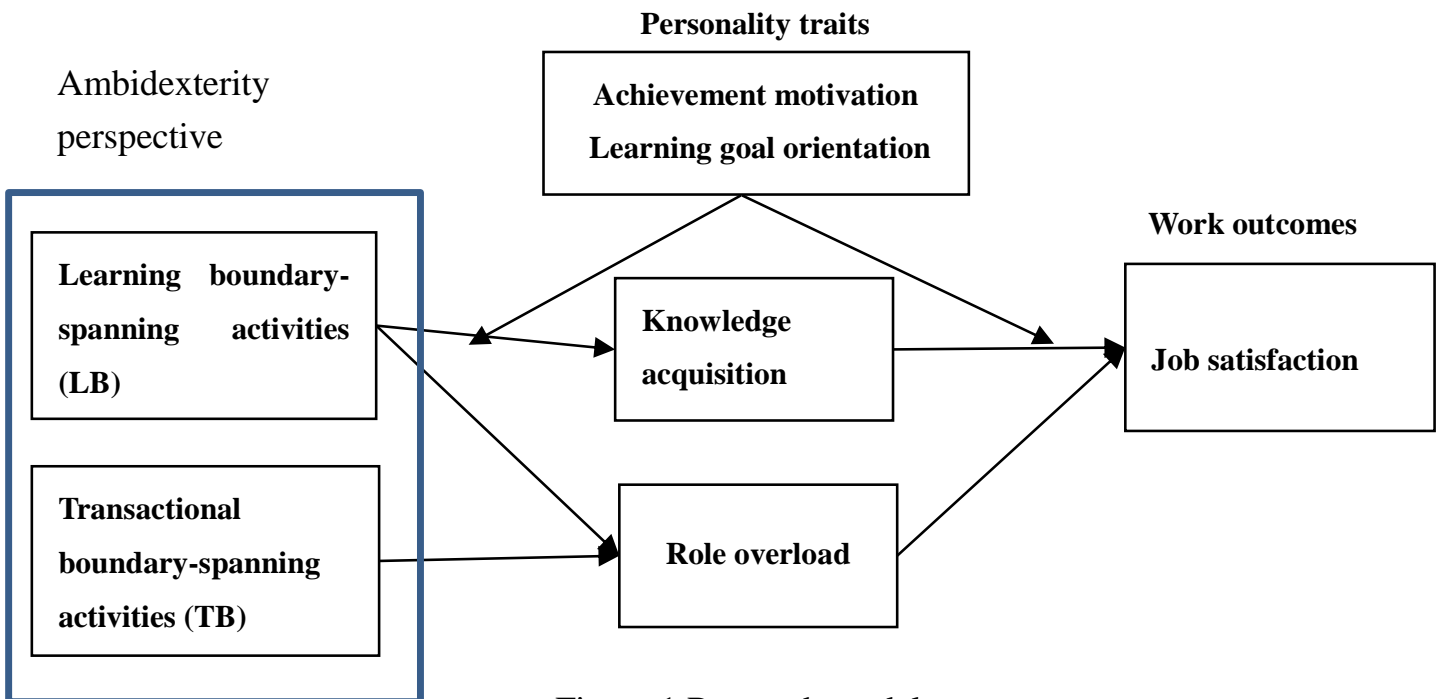

Figure 1 Research model

Table 1 Descriptive statistics and correlation coefficient of the variables

\begin{tabular}{lccccccccccc}
\hline & M & SD. & 1 & 2 & 3 & 4 & 5 & 6 & 7 & 8 & 9 \\
\hline 1. Job satisfaction & 4.7 & 1.13 & $(0.91)$ & & & & & & & & \\
2. Role overload & 4.4 & 1.10 & $-.25^{* *}$ & $(0.82)$ & & & & & & & \\
3. Knowledge acquisition & 5.1 & 0.94 & $.44^{* *}$ & 0.07 & $(0.88)$ & & & & & & \\
4. Transactional boundary- & 3.9 & 1.58 & 0.04 & $.34^{* *}$ & $.24^{*}$ & $(0.83)$ & & & & & \\
spanning activities & & & & & & & & & & & \\
5. Learning boundary-spanning & 4.6 & 1.07 & $.31^{* *}$ & 0.09 & $.44^{* *}$ & 0.19 & $(0.74)$ & & & & \\
activities & & & & & & & & & & & \\
6. Achievement motivation & 5.2 & 0.94 & $.31^{* *}$ & 0.09 & $.25^{* *}$ & 0.02 & $.37^{* *}$ & $(0.87)$ & & & \\
7. Learning goal orientation & 5.5 & 0.82 & $.26^{* *}$ & 0.11 & $.25^{* *}$ & 0.09 & $.19^{*}$ & $.63^{* *}$ & $(0.86)$ & & \\
8. Job autonomy & 3.1 & 1.34 & 0.02 & $.20^{*}$ & $-.19^{* *}$ & $.20^{*}$ & -0.02 & 0.03 & 0.03 & $(0.89)$ & \\
9. Equity of reward & 4.1 & 1.29 & $.49^{* *}$ & -0.12 & $.27^{* *}$ & 0.01 & 0.01 & 0.10 & 0.05 & -0.08 & $(0.94)$ \\
\hline
\end{tabular}

Note: $* * \mathrm{p}<0.01, * \mathrm{p}<0.05$, Cronbach $\alpha$ values of construct reliability are in parentheses. 
Table 2 Results of Hierarchical Regression

\begin{tabular}{|c|c|c|c|c|c|c|c|c|c|c|c|c|c|c|}
\hline \multirow[b]{2}{*}{ Variables } & \multirow[b]{2}{*}{ Model 1} & \multicolumn{3}{|c|}{ Role overload } & \multicolumn{4}{|c|}{$\begin{array}{l}\text { Knowledge } \\
\text { acquisition }\end{array}$} & \multirow[b]{2}{*}{ Model 1} & \multicolumn{5}{|c|}{ Job satisfaction } \\
\hline & & VIF & Model 2 & VIF & Model 1 & VIF & Model 2 & VIF & & VIF & Model 2 & VIF & Model 3 & VIF \\
\hline \multicolumn{15}{|l|}{ Step 1} \\
\hline Gender & $\begin{array}{l}.24 \\
(.24)\end{array}$ & 1.065 & $\begin{array}{l}.27 \\
(0.23)\end{array}$ & 1.066 & $\begin{array}{l}-.31 \\
(.19)\end{array}$ & 1.065 & $\begin{array}{l}-.27 \\
(.17)\end{array}$ & 1.065 & $\begin{array}{l}-.10 \\
(.21)\end{array}$ & 1.065 & $\begin{array}{l}-.07 \\
(.20)\end{array}$ & 1.066 & $\begin{array}{l}.10 \\
(.19)\end{array}$ & 1.114 \\
\hline Age & $\begin{array}{l}.01 \\
(.21)\end{array}$ & 1.868 & $\begin{array}{l}.02 \\
(.20)\end{array}$ & 1.948 & $\begin{array}{l}.14 \\
(.17)\end{array}$ & 1.868 & $\begin{array}{l}.00 \\
(.15)\end{array}$ & 1.937 & $\begin{array}{l}.30 \\
(.183)\end{array}$ & 1.868 & $\begin{array}{l}.20 \\
(.18)\end{array}$ & 1.948 & $\begin{array}{l}.19 \\
(.16)\end{array}$ & 1.951 \\
\hline Education background & $\begin{array}{l}.15 \\
(.21)\end{array}$ & 1.115 & $\begin{array}{l}0.18 \\
(.20)\end{array}$ & 1.118 & $\begin{array}{l}-.31 * \\
(.17)\end{array}$ & 1.115 & $\begin{array}{l}-.31 * * \\
(.15)\end{array}$ & 1.115 & $\begin{array}{l}-.15 \\
(.18)\end{array}$ & 1.115 & $\begin{array}{l}-.16 \\
(.18)\end{array}$ & 1.118 & $\begin{array}{l}.01 \\
(.16)\end{array}$ & 1.172 \\
\hline Work time & $\begin{array}{l}.10 \\
(.15)\end{array}$ & 1.708 & $\begin{array}{l}.04 \\
(.14)\end{array}$ & 1.757 & $\begin{array}{l}-.11 \\
(.12)\end{array}$ & 1.708 & $\begin{array}{l}-.09 \\
(.10)\end{array}$ & 1.717 & $\begin{array}{l}-.31 * * \\
(.13)\end{array}$ & 1.708 & $\begin{array}{l}-.30 * * \\
(.12)\end{array}$ & 1.757 & $\begin{array}{l}-.24 * * \\
(.11)\end{array}$ & 1.771 \\
\hline Positions & $\begin{array}{l}.06 \\
(.20)\end{array}$ & 1.288 & $\begin{array}{l}.06 \\
(.19)\end{array}$ & 1.315 & $\begin{array}{l}-.01 \\
(.16)\end{array}$ & 1.288 & $\begin{array}{l}-.10 \\
(.14)\end{array}$ & 1.314 & $\begin{array}{l}.43^{* *} \\
(.17)\end{array}$ & 1.288 & $\begin{array}{l}.37 * * \\
(.17)\end{array}$ & 1.315 & $\begin{array}{l}.42 * * * \\
(.15)\end{array}$ & 1.320 \\
\hline Job autonomy & $\begin{array}{l}.16^{* * *} \\
(.08)\end{array}$ & 1.108 & $\begin{array}{l}.11 \\
(.08)\end{array}$ & 1.158 & $\begin{array}{l}-.13 * \\
(.07)\end{array}$ & 1.108 & $\begin{array}{l}-.12 * * \\
(.06)\end{array}$ & 1.109 & $\begin{array}{l}-.01 \\
(.07)\end{array}$ & 1.108 & $\begin{array}{l}.00 \\
(.07)\end{array}$ & 1.158 & $\begin{array}{l}.09 \\
(.07)\end{array}$ & 1.283 \\
\hline Equity of reward & $\begin{array}{l}-.08 \\
(.08)\end{array}$ & 1.057 & $\begin{array}{l}-.09 \\
(.08)\end{array}$ & 1.063 & $\begin{array}{l}.16^{* *} \\
(.07)\end{array}$ & 1.057 & $\begin{array}{l}.16^{* * * *} \\
(.06)\end{array}$ & 1.062 & $\begin{array}{l}.38 * * * \\
(.07)\end{array}$ & 1.057 & $\begin{array}{l}.38 * * * \\
(.07)\end{array}$ & 1.063 & $\begin{array}{l}.30 \\
(.07)\end{array}$ & 1.139 \\
\hline \multicolumn{15}{|l|}{ Step 2} \\
\hline $\begin{array}{l}\text { Transactional boundary- } \\
\text { spanning activities }\end{array}$ & & & $\begin{array}{l}.22 * * * \\
(.07)\end{array}$ & 1.097 & & & & & & & $\begin{array}{l}-.01 \\
(.06)\end{array}$ & 1.097 & $\begin{array}{l}.01 \\
(.06)\end{array}$ & 1.254 \\
\hline $\begin{array}{l}\text { Learning boundary-spanning } \\
\text { activities }\end{array}$ & & & $\begin{array}{l}.03 \\
(.10)\end{array}$ & 1.139 & & & $\begin{array}{l}.40 * * * \\
(.07)\end{array}$ & 1.106 & & & $\begin{array}{l}.29 * * * \\
(.09)\end{array}$ & 1.139 & $\begin{array}{l}.16^{*} \\
(.09)\end{array}$ & 1.446 \\
\hline Step 3 & & & & & & & & & & & & & & \\
\hline Role overload & & & & & & & & & & & & & $-.29 * * *$ & 1.236 \\
\hline
\end{tabular}




\begin{tabular}{|c|c|c|c|c|c|c|c|c|}
\hline \multirow{3}{*}{\multicolumn{2}{|c|}{ Knowledge acquisition }} & & & & & \multicolumn{3}{|c|}{$(.08)$} \\
\hline & & & & & & & $.37 * * *$ & 1.642 \\
\hline & & & & & & & \multicolumn{2}{|l|}{$(.11)$} \\
\hline Value of $F$ & 1.22 & $2.30 * *$ & $2.82 * *$ & $6.83 * * *$ & $7.50 * * *$ & $7.60 * * *$ & \multicolumn{2}{|l|}{$9.46^{* * *}$} \\
\hline$R^{2}$ & .08 & .17 & .16 & .35 & .34 & .41 & \multicolumn{2}{|l|}{.52} \\
\hline$\Delta R^{2}$ & & $.09 * *$ & & $.19 * *$ & & $.07 * *$ & \multicolumn{2}{|l|}{$.11 * *$} \\
\hline
\end{tabular}

Note: regression coefficient (the standard deviation): $* * * \mathrm{p}<0.01, * * \mathrm{p}<0.05,{ }^{*} \mathrm{p}<0.1$ 
Table 3 Results of Parameter Estimation

\begin{tabular}{lllllllllll}
\hline $\begin{array}{l}\text { Mediating } \\
\text { variables }\end{array}$ & $a_{X 5}$ & $a_{Z 5}$ & $a_{X Z 5}$ & $R^{2}$ & $b_{X 20}$ & $b_{M 20}$ & $b_{Z 20}$ & $b_{X Z 20}$ & $b_{M Z 20}$ & $R^{2}$ \\
\hline $\begin{array}{l}\text { Achievemen } \\
\text { t motivation }\end{array}$ & $.36^{* * *}$ & .15 & $.19 * *$ & .26 & .05 & $.46^{* *}$ & $.23 *$ & -.04 & .08 & .25 \\
$\begin{array}{l}\text { Learning } \\
\text { goal }\end{array}$ & $.37 * * *$ & .19 & $.20^{* *}$ & .27 & .13 & $.44 * * *$ & .21 & -.10 & -.04 & .24 \\
orientation & & & & & & & & & & \\
\hline
\end{tabular}

Note: $* * * \mathrm{p}<0.01, * * \mathrm{p}<0.05, * \mathrm{p}<0.1 . a_{X 5}, a_{Z 5}, a_{X Z 5}$ are the non-standardized coefficients of equation (1); $b_{X 20}, b_{M 20}, b_{Z 20}, b_{X Z 20}, b_{M Z 20}$ are the non-standardized coefficients of equation (2).

Table 4 Analysis Results of Moderated Mediation Effect

\begin{tabular}{|c|c|c|c|c|c|}
\hline & \multicolumn{2}{|c|}{ Phase } & \multicolumn{3}{|c|}{ Effect } \\
\hline & The first phase & The second phase & Direct effect & Indirect effect & Total effect \\
\hline \multicolumn{6}{|c|}{ Achievement } \\
\hline \multicolumn{6}{|l|}{ motivation } \\
\hline Low & $.19 * *$ & $.38 * *$ & .09 & $.07 * *$ & .17 \\
\hline High & $.56^{* * *}$ & $.54^{*}$ & .01 & $.30 * *$ & $.31 *$ \\
\hline Difference & $.36 * *$ & .16 & -.08 & .23 & .15 \\
\hline \multirow{2}{*}{\multicolumn{6}{|c|}{$\begin{array}{l}\text { Learning goal } \\
\text { orientation }\end{array}$}} \\
\hline & & & & & \\
\hline Low & $.20 * *$ & $.47 * *$ & .21 & $.10 * *$ & $.31 * *$ \\
\hline High & $.53 * * *$ & $.41 *$ & .05 & $.22 *$ & .26 \\
\hline Difference & $.33 * *$ & -.06 & -.17 & .12 & -.04 \\
\hline
\end{tabular}

Note: The high group and low group are plus or minus one standard deviation of the moderating variable on average; the difference value is the coefficient of the high group minus that of low group, and the significance is determined by the bias-corrected confidence intervals after 1000 repetitions of the bootstrap method. $* * * \mathrm{p}<0.01, * * \mathrm{p}<0.05, * \mathrm{p}<0.1$ 


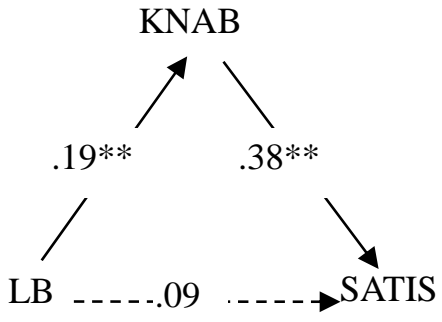

Figure 2a Mediating effect of achievement motivation in low group

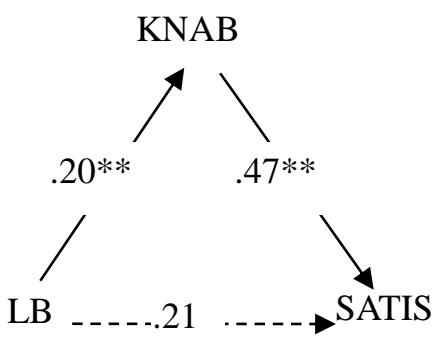

Figure 2c Mediating effect of learning goal orientation in high group

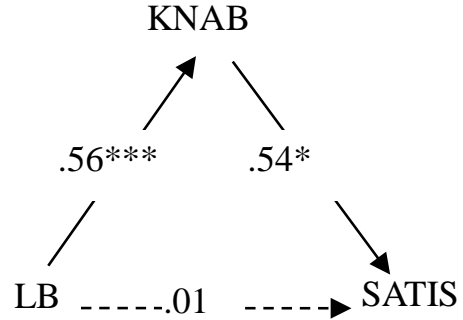

Figure $2 b$ Mediating effect of achievement motivation in high group

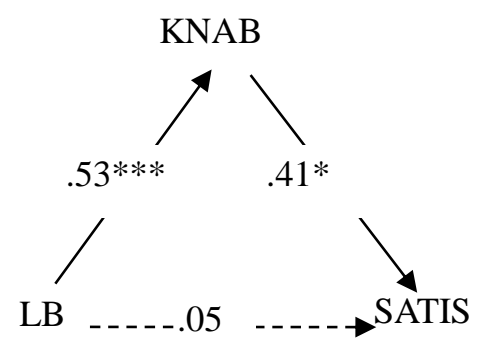

Figure 2d Mediating effect of learning goal orientation in high group

Note: LB, KNAB, SATIS are respectively for learning boundary-spanning activities, knowledge acquisition and job satisfaction. $* * * \mathrm{p}<0.01, * * \mathrm{p}<0.05,{ }^{*} \mathrm{p}<0.1$

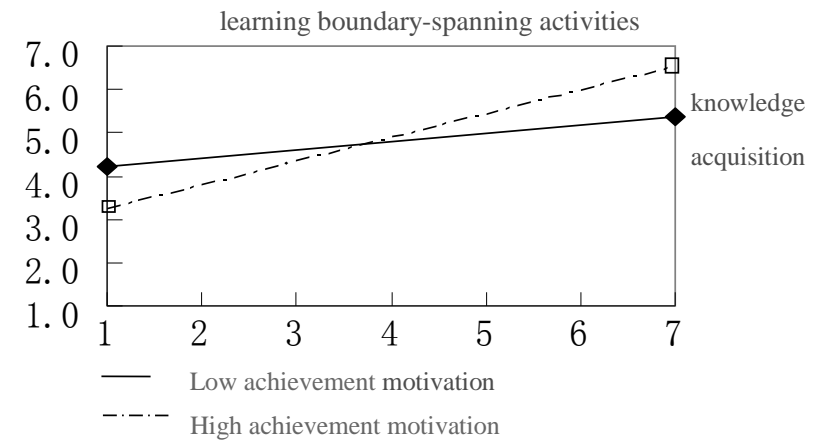

Figure 3a Moderating effect of achievement motivation

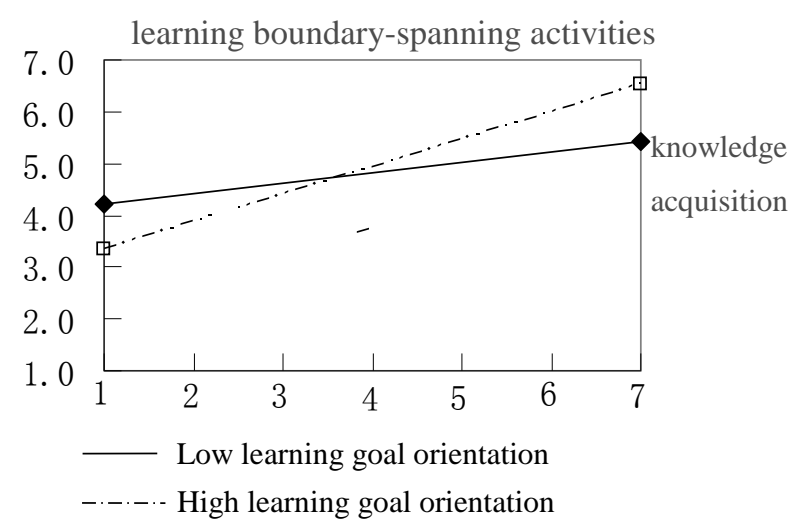

Figure $3 b$ Moderating effect of learning goal orientation 